\title{
Stress distribution analysis of seat and non-seat preparation design for orden cast post using 2D finite element method
}

\author{
Aldilla Miranda*, Gantini Subrata**), Zulia H. ${ }^{* * *}$, Tatacipta Dirgantara**** \\ *Department of Periodontic Faculty of Dentistry Universitas Padjadjaran, Bandung \\ **Department of Prosthodontic Faculty of Dentistry Universitas Padjadjaran, Bandung \\ ***Department of Dental Material and Technology Science Faculty of Dentistry Universitas \\ Padjadjaran, Bandung \\ ****Department of Mechanical and Aerospace Engineering Faculty Bandung Institute of Technology
}

\begin{abstract}
Post is used to retain a core that support the definitive restoration. One of the important factor in the prognosis of post endodontic restoration system is the post space preparation design which effects to the distribution of stresses. The purpose of this study was to analyze the effect of post space preparation design at cervical area of the root to the stress distribution on static loading using (two dimension) finite element method. This was a numeric simulation study using two $2 \mathrm{D}$ digital models: seat and non-seat design of maxillary central incisors using commercial software of finite element. The procedures of pre-processing, solution, and post-processing were used to evaluate the distribution of internal stress caused by static loading $110 \mathrm{~N}$ which was applied at $135^{\circ}$ angle with tooth longitudinal axis on the palatal surface of the core. Both models of restoration with cast post-core of Orden alloy were divided in 15,400 triangular elements. This study showed that the stress distribution from loading location to the location of stress concentration and the value of maximum stress at cervical part of the root at non-seat design were lower than the seat design (seat design 3.69 times greater than non-seat). This study proved that non-seat design distributes stress better than seat design.
\end{abstract}

Key words: Stress distribution, seat design, non-seat design, 2D finite element method

\section{ABSTRAK}

Pasak digunakan untuk mempertahankan inti dalam penyangga restorasi tetap. Salah satu faktor penting dalam prognosis setelah perawatan endodontik adalah mempersiapkan desain preparasi pasak yang berpengaruh terhadap distribusi tegangan. Tujuan penelitian ini adalah untuk menganalisis pengaruh desain preparasi pasak di daerah servikal akar terhadap distribusi tegangan pada pembebanan statis menggunakan metode elemen hingga 2 dimensi (2D). Penelitian ini merupakan metode simulasi numerik menggunakan dua model digital 2D: desain seat dan non-seat dari gigi insisivus sentral rahang atas menggunakan perangkat lunak komersial elemen hingga. Prosedur pre-processing, solution, dan post-processing digunakan untuk mengevaluasi distribusi tegangan internal yang disebabkan oleh pembebanan statis $110 \mathrm{~N}$ yang diaplikasikan dengan sudut $135^{\circ}$ terhadap sumbu panjang gigi pada permukaan palatal inti. Kedua model restorasi pasak-inti cor orden ini dibagi dalam 15.400 elemen- 
elemen segitiga. Penelitian ini menghasilkan gambaran distribusi tegangan dari tempat pembebanan ke tempat konsentrasi tegangan, dan nilai tegangan maksimum pada bagian servikal akar desain non-seat lebih rendah dari desain seat (desain seat 3,69 kali lebih besar dari non-seat). Penelitian ini membuktikan bahwa desain non-seat mendistribusikan tegangan lebih baik dari desain seat.

Kata kunci: Distribusi tegangan, desain seat, desain non-seat, 2D metode elemen hingga

\section{INTRODUCTION}

The undergraduate students of the Faculty of Dentistry Universitas Padjadjaran are required to make post-crown restorations using a custom post. For many years, the material usually used was Orden (Cu-Zn alloy)..$^{1,2}$ A post is function to retain a core. The most important factor in determining the success rate of post placement is the evenly distribution of stress from the post to the root in order to prevent root fracture. ${ }^{3}$ One of the factors that have influenced in the stress distribution from the post to the root was the root canal preparation design at cervical area as well as how much tooth structures is remained. ${ }^{4}$

Root canal preparation design at the cervical part for a cast post-core restoration that frequently used in Prosthodontic Installation of Oral and Dental Hospital Faculty of Dentistry Universitas Padjadjaran Bandung was seat design. Seat design was required the preparation of the seat and subsequently reduction of more root structure. With the seat preparation, it was hoped that a weak cast post material (i.e Orden) could resist bending at the cervical area. ${ }^{5}$ However, this statement was in the contrary with other authors that suggested to preserve more dentine structure around the post which associated with the stress distribution and resistance to fracture..$^{4,6}$ Another design that preserve more tooth structures in the cervical area is the non-seat design. ${ }^{7}$ The previous laboratory study showed that non-seat design which preserve more dentine structure around the post, makes the root more resistant to fracture..$^{1,4,8}$ Different root canal preparation designs at the cervical area will produce different patterns of stress distribution. ${ }^{9}$ This is related to the amount of dentine structure left in situ.

Cast post-core restoration is placed into root canal by cementation. ${ }^{5,7,10}$ Lutting cement usually used at the Prosthodontic Installation were Zinc Phosphate cement and Polycarboxylate cement.
Studies done in the field of dentistry about dental materials, tooth structure, preparation designs and various restorations are expensive, time consuming and technically sensitive. The difficulties encountered in those studies includes: difficulties in collecting homogenous teeth samples, difficulties in the procedure of making identical restorations, difficulties in the production and using of tools or jigs for the physical and mechanical test, difficulties in giving the identical treatments to each sample. Moreover, the internal stress mechanism in the hard structure such as enamel, dentine, and bone are difficult to determine, especially at the time of mastication. Therefore, to overcome all the limitations and difficulties mentioned above, this study utilized the computer simulation that was the finite element method/FEM or finite element analysis/FEA. This system has many advantages, for examples, it makes the laboratory procedures become easier whereby a sample can be analyzed under different treatments in a simulation condition, data analysis can be run in details, more time saving, and cost effective because the specimens production and complex testing implementation are no longer needed. ${ }^{11-15}$

In conclusion, the author was interested to analyze the influence of two types of two root canal preparation designs at cervical area for Orden cast-post towards the stress distribution that was produced by the static loading using 2D finite element method. The aim of this study was to compare the stress distribution and the maximum stress ratio in seat design to non-seat design for the Orden cast-post. This was to provide useful and evidence-base information to the staff at Prosthodontic Installation and other dental practitioners about which root canal preparation design to prevent root fracture. This study also introduces and promotes the usage of finite element method in Prosthodontic Installation the Faculty of Dentistry Universitas Padjadjaran, so 
that any studies related to structure, design and dental products can be carried out more efficient, accurate, and cost-effective.

\section{METHODS}

The aim of this study was to analyze the stress distribution from cast-post to the tooth structure in a given static loading. ${ }^{13}$ Root canal preparation design: seat and non-seat would be evaluated. The testing devices were a set of personal computer and a commercial finite element software.

Study procedures were the phase of preprocessing, solution/solving, post-processing, and data analysis. ${ }^{13,14,16}$ At the pre-processing phase, the tooth anatomy design were made manually in millimeter blocks paper. Then it, were copied in the software program in 2D models of maxillary central incisor in sagital view.

Two models were made: one with seat design and the other was non-seat (Fig. 1). The element type used here was triangular and each models was meshed into 15,400 elements. Then, creating material phase was done by giving the modulus elasticity and poisson ratio of dentine, guttapercha, and orden. The tooth was supported by the fixed outer surface of the root to resist displacement, that is the boundary condition. ${ }^{9} \mathrm{~A}$ static load of $110 \mathrm{~N}$ was applied $135^{\circ}$ toward the long axis at the palatal side of the core to simulate the anterior normal bite in the mouth. ${ }^{17}$

At solution/solving phase, the result of preprocessing was then processed using the analyzing software. The software received all of the inputs and created numerical outputs. All the calculations were done by formulating equities and combining them automatically. Solution of structural problem was displayed by the stress value of every element being loaded.

Post-processing phase was functioned to display the analytic parameter (i.e: stress). The result was displayed as pictures showing the stress distribution pattern and also displaying the maximum stress concentration values included it's locations critical area in the models.

Data was qualitativly analyze by observing the stress distribution pattern through color changes at the models which have been loaded. For quantitative analysis, it was observed by identifying the ratio of maximum stress value at the critical area of both models.

\section{RESULTS}

Color changes were seen along the surface of loading point and then spread to the cervical area. The increase in color spectrum at the loading location and cervical area showed that there were stress concentration at that locations. At the cervical area of both models (seat and non-seat), the stress concentrated occurs at the labial part. The level of the color spectrum of seat design (red) at the cervical area (critical area) was higher than non-seat design (blue) (Fig. 2 and 3).

The value was obtained from the ratio of maximum stress value between seat design at $1520 \mathrm{MPa}$ and non-seat at $412 \mathrm{MPa}$, that was:

MaximumStressRatio $=\frac{\sigma_{\text {SeatDesign }}}{\sigma_{\text {Non-searDesign }}}=\frac{1520}{412}=3.69$

Maximum stress ratio at the critical area of seat against non-seat design was 3.69 or the maximum stress value at the cervical area of seat design was 3.69 times higher than non-seat design.

\section{DISCUSSION}

Oral rehabilitation is a difficult procedure because there are functional and masticatory forces that involved a complex responses. ${ }^{18}$ In this study, simplification procedure was done by using computer simulation. Analysis of static loading effect to stress distribution was done. Root canal preparation design was seat and non-seat.

At Prosthodontic Installation of Oral and Dental Hospital Universitas Padjadjaran, Orden alloy was usually used as cast post material due to its economical benefit and the ease of fabrication and manipulation. Orden alloy is the mixture of copper and zinc $\mathrm{c}^{1,2}$ which is considered as weak and soft alloy. ${ }^{5}$ As previously proved, masticatory stress or force was distributed from a higher elastic modulus material to the lower one. It was postulated that the softer the post material was (elastic modulus is similar to dentine), the more even the stress distribution from the post to tooth structure was. ${ }^{18}$

Root canal preparation design for cast post 
inaccurate of laboratory study procedures. , $13 \cdot 15,19^{-19}$ According to several studies using finite element method for solving a simple problem i.e stress distribution caused by static loading, the use of two dimensional (2D) models is sufficient to describe phenomena which might occur. 11,12,19

Maximum stress value at a loading location (palatal area of the core) for both designs are similar. Meanwhile, the concentration of the stress at the cervical area of the root which is identified as the critical area, showed that the non-seat design has a lower level of color spectrum (blue) than seat design (red). Maximum stress value which occured at the critical area of seat design was 3.69 times higher than the non-seat design. Higher maximum stress value at seat design showed that the stress is not evenly distributed. For seat design, there are more dentine removal at the cervical area of the root structure which resulting in different thickness of dentine structure. Thus, the stress distribution to the root dentine will be more complex and will encourage stress concentration at one location. ${ }^{6}$

Though the purpose of seat design is to resist the weak post from bending at cervical area, it will endanger tooth structure because it removes more dentine structure at cervical area. On the other hand, preserving more tooth structure to increase resistance to fracture is more important. Conserving the dentine around the post will give strength and resistance against root fracture..$^{4,20}$ In addition, Gutmann and Lovdahl ${ }^{3}$ then stated that excessive tooth preparation will increase stress at the root and root fracture usually occurs with minimum coronal structure involvement. This study demonstrated the similar results and supported the result of previous laboratory study by Pramanik $^{8}$ which concluded that preserving more dentine structure will minimize the risk of root fracture. The increase of stress value in one location indicates that stress is concentrated in that location and stress distribution is uneven. ${ }^{6}$ From the justification stated above, it is concluded that non-seat design distributes stress more evenly than the seat design which is showed by the low stress value of non-seat design at the location of stress concentration.

This study was an initial study which need a further research due to its limitation, such as: the usage of $2 \mathrm{D}$ models, the usage of static loading, the absence of cement as lutting material, and the absence of periodontal structure. Long term clinical study is needed to re-evaluate the success rate of several root canal preparation designs for cast posts at anterior teeth. Design that preserve more tooth structure to prevent root from fracture should be introduce and used regularly.

\section{CONCLUSION}

Based on this study, a conclusion can be drawn as follows: (1) the stress was distributed from the loading location to the dentin in the cervical area of preparation and part of cast post restorati; (2) the stress concentration was located at the labial part of the cervical area for both designs; and (3) the maximum stress value of nonseat root canal preparation design at cervical area for Orden cast post was lower than seat design, which showed that non-seat design distributes stress more evenly than seat design.

\section{ACKNOWLEDGEMENTS}

This study was supported by Hibah Kompetensi Programme DIKTI, abstract was published on Archives of Orofacial Sciences Volume 3 Issue 2, 2008 , and it has been presented on oral presentation at The $6^{\text {th }}$ Student Scientific Conference 2008 School of Dental Sciences Universiti Sains Malaysia.

\section{REFERENCES}

1. Ash MM. Wheeler's dental anatomy, physiology \& occlusion. Philadelpia: W.B. Saunders Co.; 1993. p. 130.

2. Asmussen E, Peutzfeldt A, Sahafi A. Finite element analysis of stresses in endodontically treated, dowel-restored teeth. J Prosthet Dent 2005;94(4):321-9.

3. Cohen S, Hargreaves KM. Pathways of the pulp. $9^{\text {th }}$ ed. Missouri: Mosby; 2006. p. 786-810.

4. Dejak B. Mlotkowski A, Romanowicz M. Finite element analysis in molars during clenching and mastication. J Prosthet Dent 2003;90(6):591-7.

5. Dikbas I, Tanalp J, Ozel E, Koksal T, Ersoy M. Evaluation of the effect of different ferrule designs on the fracture resistance of endodontically treated maxillary central incisors 


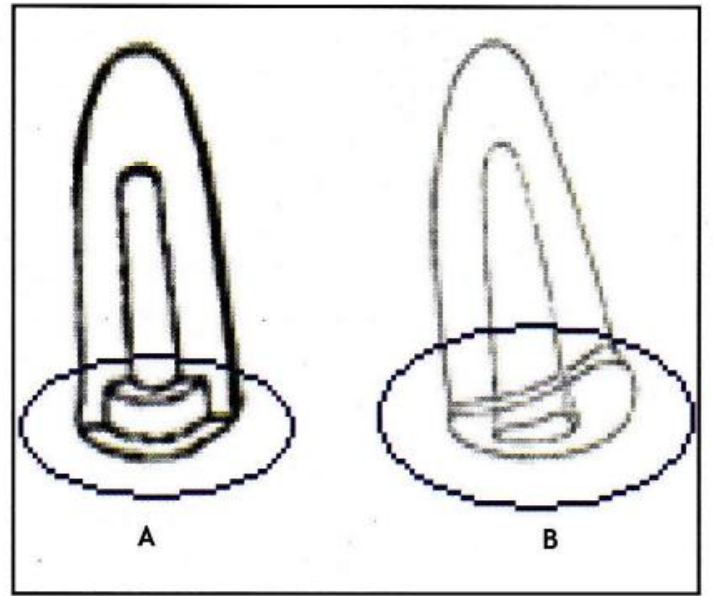

Figure 1. The data of the normal teeth geometric size is accessed from literature' (a) seat design (b) non-seat design.

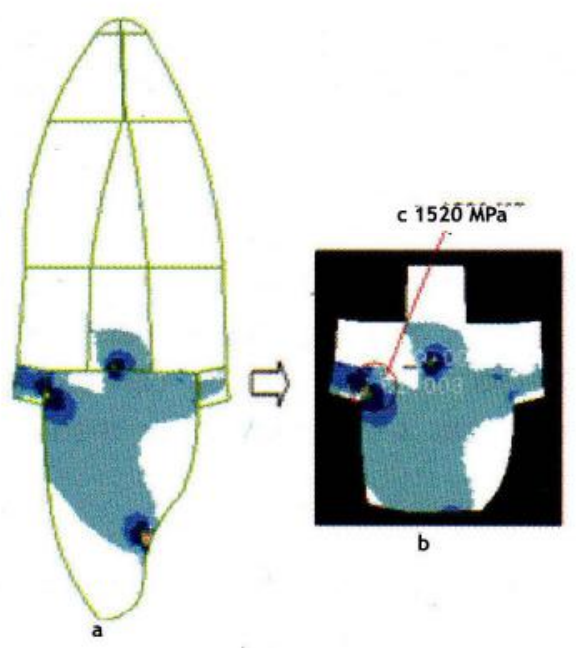

Figure 2. Pattern of stress distribution at seat design: (a) Full model; (b) Cervical area; (c) Maximum stress value at $1520 \mathrm{MPa}$.

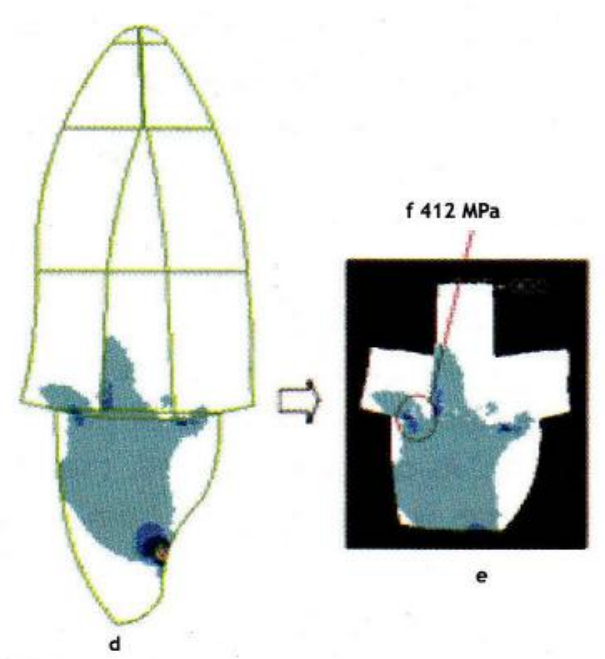

Figure 3. Pattern of stress distribution at seat design at non-seat design. (d) Full model; (e) Cervical area; (f) Maximum stress value at $412 \mathrm{MPa}$ which is also related to the remaining of the tooth structure influences the stress distribution within the restoration. Different root canal preparation design will also result in different stress distribution patterns. Stress distribution is also related to the restorative dental material and tooth structure. ${ }^{6}$ Restorative material used in this study was Orden. Meanwhile, the tooth structure is the design of preparation in the cervical area of the root. The two factors mentioned above, in the biomechanical function, will arise stress which is distributed to tooth structure and restoration. Uneven stress distribution can result a higher stress concentration at certain location. Based on the result of this study, color spectrum level at the loading location and at the cervical area of the root showed a blue to red color, while at the apical part, the spectrum showed a white color. The higher the color spectrum, the higher the stress value is. The red and blue color spectrum have stress value higher than white. It is clearly showed that at the apical part of the root, stress concentration does not occur. The stress concentration detected at one area indicate that the stress distribution is uneven. ${ }^{6}$

Root canal preparation design at cervical area used at Prosthodontic Installation of oral and Dental Hospital Universitas Padjadjaran is the seat design. The seat design, removes more dentine structure for the seat preparation about $1 \mathrm{~mm}$ deep into the root canal to prevent a weak post from bending at the cervical area. ${ }^{5}$ It will reduce the amount of sound tooth structure left in situ which finally will cause stress concentration at one area. ${ }^{3,6}$ Shillingburg et al. ${ }^{7}$ did the root canal preparation without making seat, that is the nonseat which preserved more dentine structure. The advantage of this design is increase the resistance against the root fracture. ${ }^{8}$

For the fabrication of a cast post, several concepts should be taken into consideration, including root canal preparation design and cast post material. ${ }^{15}$ Finite element method that utilized computer simulation is an excellent method to study the mechanical characteristics of a restoration. Application of force to the model will result a stress value which are distributed at every nodal point. It cannot be detected clinically. This method serves as an alternative to the relatively difficult, expensive, and technically 
percentage by $45 \%$. The fifth group, there was an increase in the number of cells apoptosis in $600 \mu \mathrm{g} / \mathrm{ml}$ concentration with apoptosis average percentage by $61 \%$. The sixth group, there was an increase in the number of cells apoptosis in $700 \mu \mathrm{g} / \mathrm{ml}$ concentration with apoptosis average percentage by $65 \%$, and there was not yet any decrease in apoptosis percentage. The apoptosis percentage of tongue cancer cells SP-C1 breed was increasing along with the increase in ethanol extract of mangosteen peel concentration. The higher the concentration of mangosteen peel extract given, the bigger apoptosis percentage would occur. Figure 1 shows mangosteen peel ethanol extract concentration with the apoptosis average percentage.

\section{DISCUSSION}

Descriptively, based on the data in Table 1 and Figure 1, it was seen that there was an effect of ethanol extract of mangosteen peel on tongue cancer SP-C1 cells apoptosis which was shown from the increase in percentage value of cells undergoing apoptosis with the increase in concentration. The apoptosis percentage of tongue cancer cells Supri's Clone-1 (SP-C1) breed was increasing along with the increase in ethanol extract of mangosteen peel concentration. Consequently, the higher the concentration of mangosteen peel extract given, the bigger the apoptosis percentage will be.

The higher concentration of mangosteen peel's ethanol extract was $700 \mu \mathrm{g} / \mathrm{ml}$. It causes an apoptosis by $65 \%$. The least apoptosis average percentage was $8 \%$, found in tongue cancer cells SP-C1 culture which was treated by ethanol extract of mangosteen peel with $300 \mu \mathrm{g} / \mathrm{ml}$ concentration. The figure shown was the $700 \mu \mathrm{g} / \mathrm{ml}$ concentration of ethanol extract shows an increase.

The research conducted by Suanto as a precursor research showed that ethanol extract of mangosteen peel possesses the power to inhibit cells growth in tongue cancer cells Supri's Clone-1 (SP-C1). The research reaches $\mathrm{IC}_{50}$ in $500 \mu \mathrm{g} / \mathrm{ml}$ concentration of ethanol extract of mangosteen peel. In $1000 \mu \mathrm{g} / \mathrm{ml}$ concentration, there was an inhibition decrease in the growth of tongue cancer cells SP-C1, this happens because of the saturation of cancer cell membrane. Cancer cells' receptor can no longer respond to higher concentration of ethanol extract of mangosteen peel. The graph showed the decrease but the decrease has not yet reaches an optimum point because the graph may rise or fall again.

The estimation result of optimum cells growth inhibition by regression statistical test was in the $706 \mu \mathrm{g} / \mathrm{ml}$ concentration and then cells growth inhibition decreases. The effect of estimation of optimum concentration of ethanol extract of mangosteen peel on tongue cancer cells SP-C1 apoptosis was $690 \mu \mathrm{g} / \mathrm{ml}$ and it was balanced. It showed that ethanol extract of mangosteen peel has an effect in inhibiting cancer cells growth because the apoptosis in the cancer cells. In normal condition, cells apoptosis and proliferation should be in balanced condition. Cells balance in tissue (tissue homeostatis) was influenced by the balance between cells undergoing proliferation and apoptosis, because each cell had the ability to maintain the number of cells in normal condition. If there was imbalance in proliferation and apoptosis, then there will be development of tumor. ${ }^{15}$

\section{CONCLUSION}

Ethanol extract of mangosteen (Garcinia mangostana Linn.) peel has an effect on tongue cancer cells Supri's Clone 1 (SP-C1) apoptosis. The $700 \mathrm{mg} / \mathrm{ml}$ concentration has the highest apoptosis percentage by $65 \%$.

\section{REFERENCES}

1. Lubis NL. Dukungan sosial pada pasien kanker, perlukah? Medan: USU Press; 2009. p. 2.

2. Sapp JP, Eversole LR, Wysocki GP. Contemporary oral and maxillofacial pathology. $2^{\text {nd }}$ ed. St. Louis: Mosby; 2004. p. 184,191.

3. Seyedmajidi $M$, Faizabadi $M$. Squamous cell carcinoma of the tongue in a 13 year old boy. Arch Iranian Med 2008;(3):341-3.

4. Desen W. Buku ajar onkologi klinik. $2^{\text {nd }}$ ed. Jakarta: Balai Penerbit FKUI; 2008. p. 32936.

5. Uripi V. Menu untuk penderita kanker. Jakarta: Puspa Swara; 2005. p. 9.

6. Sukardja IDG. Onkologi klinik. $2^{\text {nd }}$ ed. Surabaya: Airlangga University Press; 2000. p. 122-5.

7. Matsumoto K, Akao Y, Kobayashi E, Ohguchi K, 
in corporating fiber posts, composite cores and crown restorations. J Contemp Dent Pract 2007;8(7):1-10. [cited 2008 Jan 30]. Available from: http://www.thejcdp.com.

6. Eskitascioglu G, Belli S, Kalkan M. Evaluation of two post-core systems using two different methods (Fracture strength test and a finite elemental stress analysis). J Endodon 2002; 28(9):629-33.

7. Febrinaldy F. Finite elements model and verifications using MSC patran/nastran. Bandung: Creative Create Corp.; 2007. p. 3-37.

8. Fusuyama T, Ide K. Effects of type of alloys, mold temperature, and casting pressure on casting shrinkage. J Prosthet Dent 1959;9: 486.

9. Gutmann JL, Lovdahl PE. Problem solving In endodontic prevention, identification and management. St. Louis: Mosby; 1997. p. 333.

10. Khanala M, Chen Z, Zheng Y. Finite element analysis of mechanical behaviour of dental materials. Internet J Dent Sci 2006;1(2). [cited 2007 Nov 8]. Available from: http//www. google.com.

11. Logan DL. A First course in the finite element method. $3^{\text {rd }}$ ed. USA: Wadsworth Group; 2002. p. 1-21.

12. Martanto P. Teori dan praktek ilmu mahkota dan jembatan. Bandung: Angkasa; 1985. p. 40-58.

13. Pramanik RK. Uji ketahanan fraktur akar dan ketahanan pasak cor terhadap bengkok dan lepas pada preparasi saluran akar menggunak- an seat dan tanpa seat. Minor thesis. Bandung: Universitas Padjadjaran; 2007. p. 11,41.

14. Roberson TM, Heymann HO, Swift EJ. Sturdevant's art and science of operative dentistry: Dental materials. $4^{\text {th }}$ ed. St. Louis: Mosby; 2002. p. $140-8$.

15. Roensch SJ. Finite element methode: a fourarticle series. [cited 2008 Jan 30]: Available from: http//www.wikipedia.com. 2006.

16. Schwartz RS, Robbins JW. Post placement and restoration of endodontically treated teeth. J Endod 2004;30(5):289-310.

17. Shillingburg HT, Hobo $S$, Whittsett LD, Jacobi $R$, Bracket SE. Fundamentals of fixed prosthodontics. $3^{\text {rd }}$ ed. Chicago: Quintessence Publishing Co., Inc.; 1997. p. 194-206.

18. Subrata G. Penggunaan finite element analysis dalam penelitian di bidang kedokteran gigi. Proceeding Scientific Meeting of $1^{\text {st }}$ Indonesian Prosthodontics Society. Bandung: Indonesian Prosthodontics Society; 2007. p. 192-200.

19. Anggraini N, Subrata G, Hasratiningsih Z. Composition, tensile strength, and elastic modulus of Orden alloy as cast post alloy. Padjadjaran J Dentistry 2010;22(1):31-6.

20. Weine FS. Endodontic therapy. $6^{\text {th }}$ ed. St. Louis: Mosby; 2004. p. 547-60.

21. Yang $H$, Lang LA, Felton DA. Finite element stress analysis on the effect of splinting in fixed partial dentures. J Prosthet Dent 1999;81(6):721-8. 